\title{
Quality differences of retorted Samgyetangs as affected by $\mathrm{F}_{0}$-value levels
}

\author{
Jin Ho Lee, Gi Chang Song, Keun Taik Lee* \\ Department of Food Processing and Distribution, Gangneung-Wonju National University, Gangneung 25457, Korea
}

\section{레토르트 삼계탕의 $F_{0}$ 값 수준에 따른 품질 차이}

\author{
이진호 · 송기창 - 이근택* \\ 강릉원주대학교 식품가공유통학과
}

\begin{abstract}
This study was conducted to determine the $F_{0}$-values of a retort machine at different locations and to evaluate the effects of these $\mathbf{F}_{0}$-values on various quality characteristics of retorted Samgyetang samples. Samples were divided into three groups based on $\mathrm{F}_{0}$-values-T1, 10 20; T2, 20 30; T3, $>$ 30. Mineral content in Samgyetang broth and breast meat mostly increased with increasing $F_{0}$-values. In general, the free amino acid values, hardness, and springiness, except for bone springiness, of Samgyetang decreased significantly at higher $\mathbf{F}_{0}$-values. Protein content of meat and broth of the treated samples were significantly lower than that of the control. An increase in the digestion rate of meat and porridge, as well as the turbidity of the broth was observed in most of the treated samples with increasing $F_{0}$-values. With increasing $F_{0}$-values, the $L^{*}$ and $b^{*}$ values of meat and the $b^{*}$ values of broth tended to increase, while the a* value of broth increased significantly. Electronic nose analysis revealed different flavor patterns for samples treated at different $\mathbf{F}_{\mathbf{0}}$-values. For sensory traits, samples treated with higher $\mathbf{F}_{\mathbf{0}}$-values tended to receive lower evaluations. Particularly, the color and texture of T3 samples were lower than those of T1 and T2 samples. In conclusion, to improve the quality of Samgyetang, the efficiency and optimization of retort machines as well as the standardization of sterilization techniques are needed.
\end{abstract}

Key words : quality, nutrition, retort, Samgyetang, Fo-value

\section{서 론}

삼계탕은 약 4 5주령 영계의 복강에 찹쌀, 마늘, 대추와 인삼 등을 채우고 육수를 넣은 다음 장시간 가열 조리한 것으로 여름철의 보신 음식으로 많이 애용되고 있다(1). 그러나 전통적인 삼계탕은 조리하는데 시간과 노력이 많이 드는 단점이 있어, 바쁜 현대 식생활에서 복잡한 조리과정 없이 간편하게 섭취할 수 있는 즉석 취식용 편의식품으로서 레토르트 삼계탕 제품이 개발되었다(2). 레토르트 제품은

*Corresponding author. E-mail : leekt@gwnu.ac.kr Phone : 82-33-640-2333, Fax : 82-33-647-4559

Received 3 June 2016; Revised 10 October 2016; Accepted 11 October 2016.

Copyright (c) The Korean Society of Food Preservation. All rights reserved.
내열성 포장재질에 식품을 담은 후 고온고압조건 $\left(120^{\circ} \mathrm{C} / 4\right.$ 분 이상)에서 가열하여 상업적 멸균성을 부여함으로써 상 온에서 장기간 안전하게 보관이 가능하다(3). 정해진 온도 와 시간 조건하에서 미생물 수를 감소시키는 가열치사효과 $(\mathrm{L})$ 를 합한 것이 $\mathrm{F}_{0}$ 값인데, $121.1^{\circ} \mathrm{C}$ 에서 1 분 가열시 $\mathrm{F}_{0}$ 값은 1.0 으로 규정된다. 따라서 $120^{\circ} \mathrm{C} / 4$ 분 가열시 $\mathrm{F}_{0}$ 값은 약 3.1 정도로 계산된다(3). 그러나 대부분의 레토르트 삼계탕 제 품을 생산하는 업체들은 멸균지표 세균인 Clostridium botulinum 포자의 확실한 제어 및 유통과정 중 품질 안정성 을 확보하기 위하여 상기 기준을 훨씬 초과하는 열처리를 하고 있는 것으로 알려져 있다(4). 따라서 이로 인한 내용물 의 영양성분의 파괴, 조직감 저하, 이화학적 성분 변화 및 이미, 변색 또는 이취 발생 등 관능학적 품질이 저하되는 문제점이 발생되고 있다(5).

한편 레토르트 살균기의 성능이 떨어질 경우 살균기 내 
위치별 온도 편차가 심하여 같은 배치에서도 제품의 품질이 불균일하고 열화도가 높아질 가능성이 있다. Pflug와 Borrero(6)는 살균기 내 온도 분포가 살균기의 제어 시스템 의 감도, 에너지 공급 방식, 살균 매체의 흐름 방향과 속도 및 살균기 내 제품의 적재 방식 등의 요인에 의하여 차이날 수 있다고 보고하였다. Berry(7)에 의하면 살균기의 온도 편차가 $\pm 0.5^{\circ} \mathrm{C}$ 일 때 $121^{\circ} \mathrm{C}$ 살균 시 $14 \%$ 까지 살균도 차이가 날수 있다고 하였다. 그 외 레토르트 파우치의 형상(8)과 파우치 내 잔존 공기량(9), 레토르트기 형태(10), 그리고 레토르트 열순환 방식(11,12)과 레토르트 공정(13) 상의 차 이 등 다양한 요소에 의하여 최종 제품의 영양학적 품질이 영향을 받을 수 있다고 보고된 바 있다.

레토르트 삼계탕의 품질에 대하여 지금까지 삼계탕의 $\mathrm{F}_{0}$ 값 수준에 따른 실온저장 중 품질변화(3), 조리 조건과 방법 또는 조리 후의 영양성분에 미치는 영향(14), 가열증기 와 초고압을 적용한 제품 개발(15) 등 다양한 연구들이 수행 된 바 있다. 그리고 삼계탕 생산과정 중 과도한 열처리로 인해 닭 뼈가 연화되거나 포장방법 및 형태가 불안정하여 제품의 이동 및 유통과정 중 몸체가 분리되는 등 상품으로 서의 완성도가 떨어지는 문제점을 개선하기 위한 연구가 보고된 바 있다(16). 그러나 아직까지 국내 삼계탕 제조 현장에서 사용되는 레토르트 살균기내 $\mathrm{F}_{0}$ 값 분포와, 가열수 준에 따른 물리화학적, 영양학적 및 관능학적 품질 특성을 종합적으로 비교 조사한 결과는 아직 찾아보기 힘들다.

본 연구에서는 국내 삼계탕 제조 공장에서 사용하고 있 는 스팀식 레토르트기 내 위치별 $\mathrm{F}_{0}$ 값 분포를 조사하고, 이에 따른 상이한 살균도 차이가 삼계탕의 제반 품질 특성 에 어떠한 영향을 미치는지 확인하고자 하였다. 또한 이를 통하여 삼계탕 살균 처리 시 품질 차이를 최소화하고 상온 유통 및 장기저장이 가능한 삼계탕을 제조할 수 있는 가열 살균기술의 최적화 조건을 제시하고자 하였다.

\section{재료 및 방법}

삼계탕 제조 및 레토르트 살균 설계

본 실험에 사용된 레토르트 삼계탕 제품은 국내 육가공 업체에서 상법대로 제조하였다. 즉, 삼계탕 $(1,000 \mathrm{~g})$ 은 영계 의 복강 내에 부재료로서 인삼 $(15 \mathrm{~g})$, 마늘 $(5 \mathrm{~g})$, 찹쌀 $(80$ $\mathrm{g})$, 대추 $(5 \mathrm{~g})$ 등 총 $100 \mathrm{~g}$ 을 넣고 양다리를 포개 접은 후, 이를 레토르트 포장재(PET $12 \mu \mathrm{m} / \mathrm{AL} 9 \mu \mathrm{m} / \mathrm{PA} 15 \mu \mathrm{m} / \mathrm{CPP}$ $70 \mu \mathrm{m})$ 에 넣은 다음, $85^{\circ} \mathrm{C}$ 로 유지된 육수 $300 \mathrm{~mL}$ 를 충진 한 다음 즉시 밀봉기(SPM-V, Hansung, Seoul, Korea)로 열 봉함하였다. 이 때 포장 내 주입한 육수는 정제수에 엄나무 를 $100: 1$ 의 비율로 넣고 약 $90^{\circ} \mathrm{C}$ 에서 약 2 시간 동안 끓여 사전 제조하였다. 포장된 삼계탕 시료들은 레토르트 선반 한 개 당 32 개씩 올려놓은 후 한 트롤리 당 총 6단의 선반을 적재하였다. 이와 같은 방법으로 한 개의 트롤리 당 192 개, 따라서 4 개의 트롤리에 총 768 개 $(32 \times 6 \times 4)$ 의 삼계탕 시료가 적재된 상태로 스팀식 레토르트기(Goldrich, Hyup-Jin, Ansan, Korea)를 이용하여 $121^{\circ} \mathrm{C}$ 에서 75 분간 $4.6 \mathrm{~kg} / \mathrm{cm}^{2}$ 의 조건으로 가열처리하였다.

\section{레토르트 위치별 $\mathrm{F}_{0}$ 값 측정 및 시료 선발}

삼계탕 제품의 가열처리 시 내부 살균도는 $\mathrm{F}_{0}$ 값 측정용 data logger(Tracksens Pro, Ellab, Hilleroed, Denmark)를 이 용하여 닭의 복강 내에 채워진 찹쌀의 중심부에 위치한 대추 내부로 센서를 고정시킨 다음, 포장된 삼계탕 시료들 을 Fig. 1에 보이는 바와 같이 코드화시킨 후 중심온도를 측정하였다. 측정된 중심온도를 바탕으로 $\mathrm{F}_{0}$ 값을 Valsuit Pro(Version:2.8.5.0, Ellab, Hilleroed, Denmark)로 계산하였 다. 이와 같이 제조된 삼계탕 제품 중 Fig. 1의 코드로 설정된 부분에서 $\mathrm{F}_{0}$ 값 범위가 각각 10-20로 확인된 '가-C-5', 20-30 로 확인된 '가-A-12'와 '가-B-12', 그리고 30을 초과한 것으

\begin{tabular}{|l|l|l|l|}
\hline 8 & 16 & 24 & 32 \\
\hline 7 & 15 & 23 & 31 \\
\hline 6 & 14 & 22 & 30 \\
\hline 5 & 13 & 21 & 29 \\
\hline 4 & 12 & 20 & 28 \\
\hline 3 & 11 & 19 & 27 \\
\hline 2 & 10 & 18 & 26 \\
\hline 1 & 9 & 17 & 25 \\
\hline
\end{tabular}

Front $\leftrightarrow$ Rear

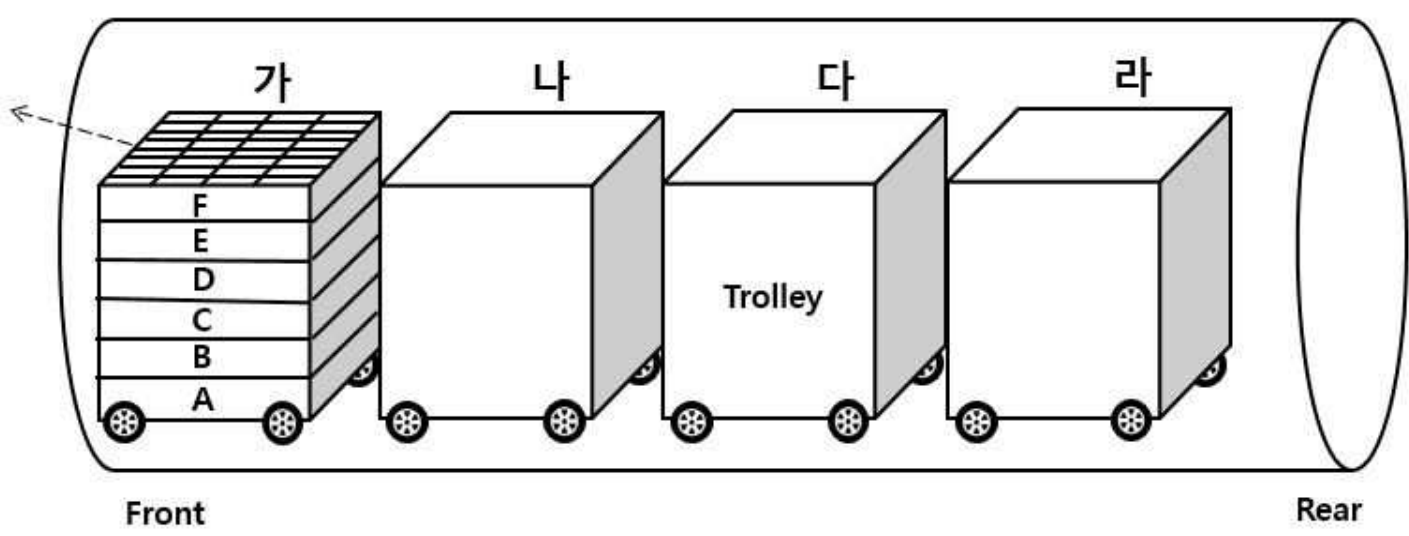

Fig. 1. Location codes of Samgyetang products inserted with temperature data loggers in a retort machine. 
로 확인된 '나-C-5'와 '가-D-12' 부분의 시료들을 각각 T1, $\mathrm{T} 2$ 및 $\mathrm{T} 3$ 처리구로, 그리고 비살균구(C)를 대조구로 설정하 였다. 한편, 본 실험의 공시시료는 동일한 조건으로 레토르 트 살균된 삼계탕을 3 회에 걸쳐 상기 코드 부분에서 선발하 여 아래와 같은 분석을 실시하였다.

\section{무기질 분석}

삼계탕의 무기질 분석을 위하여 육수와 분쇄한 가슴살 시료 $1 \mathrm{~g}$ 을 각각 microwave digestion tube에 넣고 $\mathrm{HNO}_{3}$ $4 \mathrm{~mL}(65 \%)$ 와 $\mathrm{H}_{2} \mathrm{O}_{2} 1 \mathrm{~mL}(30 \%)$ 를 각각 가한 후 microwave digestion system(Ethos 1, Milestone, Sorisole, Italia)에서 시 료를 용액화하였다. 이때 조건은 digestion 조건은 1,200 $\mathrm{W} / 190^{\circ} \mathrm{C} / 15 \mathrm{~min}$ 이었다. 그 다음 시료를 $100^{\circ} \mathrm{C}$ 로 설정된 hot plate에서 시료를 휘발시켜 $1 \mathrm{~mL}$ 로 만든 다음, $1 \% \mathrm{HNO}_{3}$ 으로 희석하여 ICP-AES(Optima 5300DV, Perkin Elmer, Waltham, MA, USA)를 이용하여 Table 2의 조건으로 무기 질 성분들을 측정하였다.

\section{단백질 정량}

육수와 가슴살 단백질 함량은 Lowry 등(17)의 방법에 따라 측정하였다. 즉, 시료 $5 \mathrm{~g}$ 을 증류수 $50 \mathrm{~mL}$ 에 녹인 후 원심분리하여 얻은 상등액 $0.2 \mathrm{~mL}$ 에 $2 \mathrm{~N} \mathrm{NaOH} 0.1$ $\mathrm{mL}$ 를 가하고 10 분간 가열한 후 상온으로 냉각시키고 여기 에 complex-forming reagent $100: 1: 1\left(\mathrm{Na}_{2} \mathrm{CO}_{3}\right.$ in DW, $\mathrm{CuSO}_{4} \cdot 5 \mathrm{H}_{2} \mathrm{O}$ in DW, $\mathrm{KNaC}_{4} \mathrm{H}_{4} \mathrm{O}_{6} \cdot 4 \mathrm{H}_{2} \mathrm{O}$ in DW) 비율의 complex-forming reagent $1 \mathrm{~mL}$ 를 가하고 10 분간 방치하였 다. 이에 Folin reagent $0.1 \mathrm{~mL}$ 를 넣고 혼합 후 30 분간 방치한 다음 spectrophotometer(V-650, Jasco, Tokyo, Japan)를 이용 하여 $750 \mathrm{~nm}$ 에서 흡광도를 측정하였다. 단백질 함량은 bovine serum albumin을 사용하여 얻어진 표준곡선을 토대 로 계산하였다.

\section{소화율}

In vitro 법에 의한 소화율 측정은 Yamashita 등(18)의 방법에 따라 삼계탕의 가슴살과 죽 시료 $0.5 \mathrm{~g}$ 을 각각 증류 수 $50 \mathrm{~mL}$ 에 용해시키고, $0.1 \mathrm{~N} \mathrm{HCl}$ 과 $0.1 \mathrm{NaOH}$ 로 $\mathrm{pH}$ 를 중성으로 조절한 다음 pepsin $10 \mathrm{mg}$ 씩을 각각 가하고 $37^{\circ} \mathrm{C}$ 에서 24시간 동안 진탕항온수조(BS-20, Jeiotech, Daejeon, $\mathrm{Korea}$ )에서 분해시켰다. 분해 완료 후 반응혼합물에 $20 \%$ trichloroacetic acid(TCA) 용액 $50 \mathrm{~mL}$ 를 가하여 원심분리기 (A32010, Gyrozen, Seoul, Korea)로 원심분리(3,100 g, 10 $\mathrm{min}$ )한 다음 상층액의 가용성 질소 함량을 Kjeldahl법으로 측정하였다.

\section{유리아미노산 조성}

가슴살 시료 $1 \mathrm{~g}$ 에 $70 \%$ 에탄올을 가하고 30 분간 진탕시 킨 다음 원심분리기(A32010, Gyrozen, Seoul, Korea)를 이용
하여 $15,000 \mathrm{rpm}$ 에서 15 분간 원심분리하여 얻은 상등액을 취하고, 남은 잔사에 다시 $70 \%$ 에탄올을 가해 원심분리하 여 얻어진 상등액을 앞서 얻은 상등액과 함께 진공농축하였 다. 이 여액에 $0.02 \mathrm{~N} \mathrm{HCL} 10 \mathrm{~mL}$ 를 가하여 용해시킨 다음 $0.20 \mu \mathrm{m}$ syringe filter로 여과한 후 high speed amino acid analyzer(L-8900, Hitachi, Tokyo, Japan)를 이용하여 Table 3 의 조건으로 분석하였다.

\section{경도 및 탄성도}

Adaptor No. 34를 장착한 rheometer(Compac-100, Sun Scientific, Tokyo, Japan)를 이용하여 가슴살과 뼈 시료의 hardness(경도)와 springiness(탄성도)를 6회씩 반복하여 측 정하였다. 측정 시 시료의 중간 부위를 직육면체의 형태로 직각 방향으로 가로와 세로를 각각 $1.5 \mathrm{~cm}$, 그리고 높이를 $1 \mathrm{~cm}$ 크기가 되도록 준비하였으며, 기기 측정 속도는 60 $\mathrm{mm} / \mathrm{min}$ 로 설정하였다.

\section{탁 도}

탁도는 육수를 $4 \pm 1^{\circ} \mathrm{C}$ 에서 하룻밤 냉장 보관한 후 위에 떠 있는 기름을 수저로 최대한 제거하고, 여지(Whatman No. 5)로 여과한 다음 분광광도계(V-650, Jasco, Tokyo, $\mathrm{Japan}$ )를 사용하여 $600 \mathrm{~nm}$ 에서 투과도를 측정하였다.

색 도

가슴살의 색도는 $\mathrm{Y}$ 값 $93.7, \mathrm{x}$ 값 0.3132 와 $\mathrm{y}$ 값 0.3192 인 백색 표준 plate를 사용하여 calibration한 다음 시료를 $1 \times 1$ $\mathrm{cm}$ 크기로 자른 뒤 colorimeter(CR-300, Minolta, Osaka, Japan)를 이용하여 CIE 명도(L", lightness), 적색도(a ${ }^{*}$, redness)와 황색도(b ${ }^{*}$, yellowness)값을 측정하였다. 육수의 색도는 500 $\mu \mathrm{m}$ 체를 이용하여 건더기를 거른 후 $10 \mathrm{~mL}$ 를 취하여 color meter(JS555, Colour Techno Corp., Osaka, Japan)를 이용하 여 측정하였다.

\section{향기 패턴 분석}

시료의 향기 패턴은 전자코(GC type E Nose Heracles II, Alpha MOS, Toulouse, France)로 분석하였다. 육수와 분쇄한 가슴살 시료 각 $1 \mathrm{~g}$ 을 vial에 넣고 자동시료채취기에 놓은 후 $60^{\circ} \mathrm{C}, 300 \mathrm{rpm}$ 으로 교반하면서 주입구 온도가 $130^{\circ} \mathrm{C}$ 인 상태에서 주입하였다. 이 때 사용한 가스는 헬륨이 었으며 분당 $50 \mathrm{~mL}$ 의 유속으로 흘려보냈고 분석 시간은 5 분이었다. Syringe purge는 3초를 유지한 후 thermostated tray holder에 놓은 다음 head space syringe를 사용하여 5 $\mathrm{mL}$ 를 취하였다. 분석에 사용된 전자코는 두 개의 column(100 $\mu \mathrm{m}$ id \#DB5, $100 \mu \mathrm{m}$ id \#DB1701)과 두 개의 FID(flame ionization detectors)에 연결되어 있었고 data는 PCA(Alpha soft version 8.01 software, Alpha MOS, Toulouse, France)로 분석하였다. 
관능검사

관능검사는 사전에 삼계탕 시료의 품질특성에 대하여 교육 및 훈련된 관능요원 10 명을 패널로 하여 외관 (appearance), 조직감(texture), 향미(flavor)와 이취(off-odor) 에 대하여 9점 기호척도법(hedonic scale)으로 실시하였다. 이때 9점 '매우 우수하다', 7점 '우수하다', 5점 '적당하다', 3점 '나쁘다', 1점 '매우 나쁘다'로 각각 평가하였다. 관능평 가 시료는 $85^{\circ} \mathrm{C}$ 로 유지되는 오븐(EOB-261T, Hanssem, Ansan, Korea)에서 15 분간 보온한 후 무작위의 3자리 숫자 코드로 표시한 PP 트레이에 담은 다음, $1,200 \mathrm{lux}$ 의 밝기를 갖는 3파장 램프로 비춘 상태로 패널에 제시되었다.

\section{통계분석}

모든 측정값들은 통계분석 프로그램인 SPSS(Version 21 software, IBM, Armonk, NY, USA)을 이용하여 수행하였고, 유의성 검정은 Duncan's multiple range test로 $p<0.05$ 수준에 서 분석하였다.

\section{결과 및 고찰}

\section{레토르트 내 위치별 $\mathrm{F}_{0}$ 값 측정}

Table 1에서 나타난 바와 같이 레토르트 내 트롤리별 삼계탕의 $\mathrm{F}_{0}$ 값 분포 결과는 '다' 트롤리에 적재된 삼계탕에 서의 $\mathrm{F}_{0}$ 값이 가장 높았고, '가' 트롤리에 적재된 삼계탕의 $\mathrm{F}_{0}$ 값이 가장 낮았던 것으로 확인되었다. '가' 트롤리를 기준 하여 보면 가장 상단부분인 ' $\mathrm{F}$ '층과 가장 하단부분인 'A'층 과 하단에서 두 번째인 ' $\mathrm{B}$ '층에서의 $\mathrm{F}_{0}$ 값 편차는 각각 44.4 와 47.5 로 확인되었다. 즉, 레토르트기내 트롤리의 층별로 $\mathrm{F}_{0}$ 값 분포가 차이났는데, 대체로 상부층이 하부층보다 높은 경향을 보였다. Chung 등(11)은 스팀식 레토르트기의 경우 열수가 처리조의 상단부분에 위치한 파이프의 구멍을 통하

Table 1. F-value measurements of retorted Samgyetang on different locations in a retort machine

\begin{tabular}{ccc}
\hline Location of data logger sensor & Code & $\begin{array}{c}\text { Measured values } \\
\left(\mathrm{F}_{0} \text {-value }\right)\end{array}$ \\
\hline \multirow{5}{*}{ Different trolley locations } & -C-5 & 18.0 \\
& 나-C-5 & 46.0 \\
& 다-C-5 & 67.0 \\
& 라-C-5 & 50.0 \\
\hline \multirow{5}{*}{ Different rack locations } & 가-A-12 & 25.6 \\
& 가-B-12 & 22.5 \\
& 가-C-12 & 54.1 \\
& 가-D-12 & 41.6 \\
& 가-E-12 & 51.0 \\
& 가-F-12 & 70.0 \\
\hline
\end{tabular}

Table 2. Instrumental parameters of ICP-OES for the analysis of minerals contained in the Samgyetang breast meat and broth

\begin{tabular}{ccc}
\hline RF power & 1300/Watts \\
Nebulizer & Seaspray \\
Pump flow rate & $1.50 \mathrm{~mL} / \mathrm{min}$ \\
Plasma flow & $15.0 \mathrm{~L} / \mathrm{min}$ \\
Auxiliary flow & $0.2 \mathrm{~L} / \mathrm{min}$ \\
Nebulizer flow & & $0.50 \mathrm{~L} / \mathrm{min}$ \\
& $\mathrm{Fe}$ & 238.204 \\
& $\mathrm{Mg}$ & 285.213 \\
Wavelength, A & $\mathrm{Ca}$ & 317.933 \\
& $\mathrm{P}$ & 213.617 \\
& $\mathrm{~K}$ & 766.490 \\
\hline
\end{tabular}

Table 3. HPLC analysis conditions for the determination of free amino acids in the retorted Samgyetangs

\begin{tabular}{cc}
\hline Parameter & Condition \\
\hline Column & Ion exchange column $(4.6 \mathrm{~mm} \times 60 \mathrm{~mm})$ \\
Column temperature & $30 \sim 70^{\circ} \mathrm{C}$ \\
& Pump $1:$ buffer solution \\
Mobile phase & Pump $2:$ ninhydrin \\
& Pump $1: 0.35 \mathrm{~mL} / \mathrm{min}$ \\
Flow rate & Pump $2: 0.3 \mathrm{~mL} / \mathrm{in}$ \\
Injection volume & $20 \mu \mathrm{L}$ \\
Reaction coil temperature & $135^{\circ} \mathrm{C}$ \\
& Channel $1: \mathrm{UV} 570 \mathrm{~nm}$ \\
Photometer & Channel $2: \mathrm{UV} 440 \mathrm{~nm}$ \\
\hline
\end{tabular}

여 분사되므로 처리조의 하단부분이 상단부분에 비하여 열수의 영향을 덜 받는다고 보고하였다. 그리고 열대류에 따라 상단 부분의 온도가 하단 부분보다 높아지는 것에도 기인할 것으로 판단된다. 반면, 냉각 시에는 냉각수가 하단 부분으로부터 들어오기 때문에 파우치의 투입량과 관계없 이 살균기 하단 부분의 온도가 빨리 떨어지고 상단 부분이 늦게 떨어짐에 따라 상단 부분의 $\mathrm{F}_{0}$ 값이 높게 나오는 데 일부 기여하는 것으로 추정된다. 한편 이러한 $\mathrm{F}_{0}$ 값 편차는 레토르트 가동 시간, 설정 압력, 적재량, 기기 성능, 제품의 내용물 및 포장형태 등의 여러 요인들에 의한 영향으로 판단된다. 따라서 레토르트 삼계탕을 가능한 한 균일한 $\mathrm{F}_{0}$ 값으로 살균하기 위해서는 살균용 선반 형태의 개조, 배관 파이프의 조정, 순환 펌프의 효율 등 레토르트기 성능 개선 이 이루어져야 할 것이다.

\section{무기질 분석}

$\mathrm{F}_{0}$ 값 수준에 따른 레토르트 삼계탕의 가슴살과 육수의 무기질 함량 변화는 Table 4에 나타난 바와 같다. 가슴살의 무기질 함량은 $\mathrm{F}_{0}$ 값 수준이 높아질수록 점차 증가하는 추세 
Table 4. Mineral contents, soluble protein, and digestion rate of retorted Samgyetang broths treated with different $\mathrm{F}_{0}$-values

\begin{tabular}{|c|c|c|c|c|c|c|}
\hline \multirow{2}{*}{\multicolumn{3}{|c|}{ Parameter }} & \multirow{2}{*}{ Control $^{1)}$} & \multicolumn{3}{|c|}{ Treatments $^{2)}$} \\
\hline & & & & $\mathrm{T} 1$ & $\mathrm{~T} 2$ & $\mathrm{~T} 3$ \\
\hline \multirow{10}{*}{$\begin{array}{l}\text { Mineral contents } \\
\quad(\mathrm{mg} / 100 \mathrm{~g})\end{array}$} & \multirow{5}{*}{ Breast } & $\mathrm{Mg}$ & $11.33 \pm 0.03^{3 / d 4)}$ & $12.63 \pm 0.02^{c}$ & $13.20 \pm 0.01^{\mathrm{b}}$ & $13.55 \pm 0.01^{\mathrm{a}}$ \\
\hline & & $\mathrm{K}$ & $58.60 \pm 0.04^{\mathrm{d}}$ & $63.65 \pm 0.01^{\mathrm{c}}$ & $66.06 \pm 0.01^{b}$ & $68.36 \pm 0.01^{\mathrm{a}}$ \\
\hline & & $\mathrm{Ca}$ & $14.71 \pm 0.00^{\mathrm{d}}$ & $18.98 \pm 0.01^{c}$ & $21.76 \pm 0.03^{b}$ & $34.87 \pm 0.01^{\mathrm{a}}$ \\
\hline & & $\mathrm{Fe}$ & $1.24 \pm 0.02^{\mathrm{d}}$ & $1.44 \pm 0.02^{\mathrm{c}}$ & $1.65 \pm 0.01^{b}$ & $1.79 \pm 0.01^{\mathrm{a}}$ \\
\hline & & $\mathrm{P}$ & $72.89 \pm 0.01^{\mathrm{d}}$ & $88.02 \pm 0.04^{\mathrm{c}}$ & $91.18 \pm 0.02^{b}$ & $97.22 \pm 0.01^{\mathrm{a}}$ \\
\hline & \multirow{5}{*}{ Broth } & $\mathrm{Mg}$ & $4.30 \pm 0.00^{d}$ & $6.80 \pm 0.01^{c}$ & $7.30 \pm 0.01^{b}$ & $8.20 \pm 0.01^{\mathrm{a}}$ \\
\hline & & K & $13.35 \pm 0.02^{\mathrm{d}}$ & $49.10 \pm 0.03^{c}$ & $52.54 \pm 0.02^{\mathrm{b}}$ & $57.72 \pm 0.02^{\mathrm{a}}$ \\
\hline & & $\mathrm{Ca}$ & $5.80 \pm 0.00^{\mathrm{d}}$ & $8.55 \pm 0.00^{\mathrm{c}}$ & $52.54 \pm 0.02^{b}$ & $57.72 \pm 0.02^{\mathrm{a}}$ \\
\hline & & $\mathrm{Fe}$ & $0.00 \pm 0.00^{\mathrm{d}}$ & $0.10 \pm 0.01^{\mathrm{c}}$ & $0.20 \pm 0.01^{b}$ & $0.50 \pm 0.02^{\mathrm{a}}$ \\
\hline & & $\mathrm{P}$ & $24.1 \pm 0.00^{\mathrm{d}}$ & $53.0 \pm 0.03^{\mathrm{c}}$ & $57.7 \pm 0.06^{b}$ & $64.3 \pm 0.06^{\mathrm{a}}$ \\
\hline \multirow{2}{*}{$\begin{array}{l}\text { Protein contents } \\
\qquad(\mu \mathrm{g} / \mathrm{mL})\end{array}$} & \multicolumn{2}{|c|}{ Breast } & $4.02 \pm 0.00^{\mathrm{a}}$ & $3.77 \pm 0.01^{\mathrm{b}}$ & $3.78 \pm 0.00^{\mathrm{b}}$ & $3.78 \pm 0.00^{b}$ \\
\hline & \multicolumn{2}{|c|}{ Broth } & $3.02 \pm 0.02^{\mathrm{a}}$ & $1.85 \pm 0.01^{b}$ & $1.85 \pm 0.00^{\mathrm{b}}$ & $1.86 \pm 0.01^{b}$ \\
\hline \multirow{2}{*}{ Digestion rate $(\%)$} & \multicolumn{2}{|c|}{ Breast } & $11.84 \pm 1.33^{\mathrm{c}}$ & $23.97 \pm 1.95^{b}$ & $38.90 \pm 1.71^{\mathrm{a}}$ & $39.40 \pm 0.93^{\mathrm{a}}$ \\
\hline & \multicolumn{2}{|c|}{ Porridge } & $44.24 \pm 0.28^{\mathrm{d}}$ & $46.03 \pm 1.02^{\mathrm{c}}$ & $51.96 \pm 1.40^{\mathrm{b}}$ & $56.96 \pm 0.58^{\mathrm{a}}$ \\
\hline
\end{tabular}

\footnotetext{
${ }^{1)}$ Control, non-retorted sample.

${ }^{2)} \mathrm{F}_{0}$-value range of treatments: T1, 10 20; T2, 20 30; T3, >30.

${ }^{3)}$ Values are mean \pm SD.

${ }^{4)-d}$ Different superscripts in the same row are significantly different $(\mathrm{p}<0.05)$
}

를 보여 T3에서 최댓값을 나타내었다. $\mathrm{T} 3$ 시료에서의 $\mathrm{Mg}$, $\mathrm{K}, \mathrm{Ca}, \mathrm{Fe}$ 및 $\mathrm{P}$ 의 시료 $100 \mathrm{~g}$ 당 최대 함량은 각각 13.55 $\mathrm{mg}, 68.36 \mathrm{mg}, 34.87 \mathrm{mg}, 1.79 \mathrm{mg}$ 및 $97.22 \mathrm{mg}$ 이었다. 육수에 서의 무기질 함량의 경우도 가슴살과 마찬가지로 $\mathrm{F}_{0}$ 값이 증가함에 따라 높아지는 경향을 보여 $\mathrm{T} 3$ 에서 최댓값을 나 타내었다. T3 육수 시료에서의 $\mathrm{Mg}, \mathrm{K}, \mathrm{Ca}, \mathrm{Fe}$ 및 $\mathrm{P}$ 의 시료 $100 \mathrm{~g}$ 당 최대 함량은 각각 $8.20 \mathrm{mg}, 57.72 \mathrm{mg}, 57.72 \mathrm{mg}$, $0.50 \mathrm{mg}$ 및 $64.3 \mathrm{mg}$ 이었다.

Park 등(14)은 냄비에서 가열한 삼계탕의 용출액 중 무기 질 함량에 관한 연구에서 가열 시간이 경과함에 따라 $\mathrm{Ca}$, $\mathrm{K}, \mathrm{Mg}, \mathrm{Zn}, \mathrm{Fe}, \mathrm{Na}$ 와 $\mathrm{P}$ 등의 용출량이 증가하였다고 보고하 였다. 살균 정도에 따라 레토르트 삼계탕의 무기질 함량이 증가하는 것은 닭 뼈나 인삼, 대추, 밤 등의 기타 부재료에서 의 무기 성분 용출량이 증가하여 육수와 가슴살에 영향을 미친 것으로 추측된다. 그러나 삼계탕 제품에서 과도한 열 처리로 육수에서의 $\mathrm{Ca}$ 이나 $\mathrm{P}$ 과 같은 무기질 함량이 크게 증가할 경우 일본 등 선진국에서는 규제가 될 수도 있으므 로 향후 이에 대한 관리가 필요할 것으로 판단된다.

\section{단백질 함량}

가열수준에 따라 삼계탕의 육과 육수에서의 단백질 용출 및 변성 등의 요인으로 함량 변화가 있을 것으로 판단되어 육과 육수에서의 단백질 함량을 비교하였다(Table 4). Smyth와 O'Neill(19)는 닭고기와 같이 주로 백색근섬유로 구성된 단백질은 대부분 염용성 단백질로서 온도에 따라
기능성과 조직감이 변한다고 보고하였다. 또한 Wattanachant 등(20)은 열처리가 단백질과 콜라겐 용해도에 중요한 영향 을 미친다고도 하였다. 본 연구에서도 육수와 가슴살의 단 백질 함량은 살균되지 않은 $\mathrm{C}$ 시료에서 각각 $3.02 \mathrm{\mu g} / \mathrm{mL}$ 과 $4.02 \mathrm{\mu g} / \mathrm{mL}$ 이었으나, 레토르트 살균 후 육수에서는 T1(1.85 $\mu \mathrm{g} / \mathrm{mL}), \mathrm{T} 2(1.85 \mu \mathrm{g} / \mathrm{mL})$ 및 T3(1.86 $\mu \mathrm{g} / \mathrm{mL})$, 그리고 가슴살 에서는 T1 $(3.77 \mu \mathrm{g} / \mathrm{mL}), \mathrm{T} 2(3.78 \mu \mathrm{g} / \mathrm{mL})$ 및 T3(3.78 $\mu \mathrm{g} / \mathrm{mL})$ 의 값을 나타내어 처리구와 비살균구 간에 유의적인 차이를 보였다 $(\mathrm{p}<0.05)$. 하지만 육수와 가슴살 시료 모두 $\mathrm{F}_{0}$ 값 수준 에 따른 단백질 함량의 유의적 차이는 나타나지 않았다 ( $>0.05$ ).

$\mathrm{Cho}(21)$ 는 소고기를 3 가지 다른 출력의 전자파 $40 \%$, $60 \%$ 와 $100 \%$ )로 조리 시 육의 내부온도가 상승할수록 단백 질 함량이 감소한다고 하였다. 또한 Son 등(22)의 열처리에 따른 콩 단백질의 알레르기항원성 변화에 관한 연구에서 콩 단백질을 $13 \%$ SDS-PAGE로 단백질의 크기에 따라 분리 한 결과 열처리에 따른 단백질 변화는 거의 관찰되지 않는 다고 보고하여 본 연구결과와는 다소 차이가 있었다. 이는 고온고압 살균 과정을 거친 레토르트 제품의 특성상 단백질 용해도가 과도하게 낮아져 $\mathrm{F}_{0}$ 값 수준에 따른 차이가 상쇄된 것에 기인한 것으로 추측된다.

\section{소화율}

$\mathrm{F}_{0}$ 값 수준이 레토르트 삼계탕 가슴살과 죽의 소화율에 어떤 영향을 미치는가를 파악한 결과는 Table 4 에 나타나 
있다. 삼계탕 가슴살의 소화율은 레토르트 처리한 시료들 의 경우 $23.97 ~ 39.40 \%$ 범위로서 비살균구(11.84\%)에 비해 높았으며 $\mathrm{F}_{0}$ 값이 높아질수록 증가하는 경향을 보였다. 삼계 탕 죽은 가슴살보다 소화율이 높아서 가열처리된 시료들의 경우 46.03 56.96\% 범위를 나타냈는데 가슴살과 마찬가지 로 비살균구(44.24\%)에 비해 유의적으로 높았고 $\mathrm{F}_{0}$ 값이 높 아질수록 증가하는 경향을 보였다(p<0.05). 이와 관련한 연 구로서 Hoppe 등(23)은 열처리가 단백질의 구조 변화를 가져오고 이에 따라 식품의 소화율이 증가한다고 하였다. 또한 Sun 등(24)은 고압증기로 멸균 시 $\left(127^{\circ} \mathrm{C} / 20 \mathrm{~min} / 0.145\right.$ $\mathrm{MPa}$ ) 시험관내 및 $\mathrm{SPP}($ sweet potato protein)의 생체 내 소화 율이 크게 향상되었다고 보고한 바 있다. 한편 Promeyrat 등(25)은 육제품의 감소하는 단백질 소화율이 인간의 건강 과 영양적 품질에 부정적인 영향을 미친다고 보고한 바 있다.

유리아미노산 조성

레토르트 삼계탕 가슴살에서의 유리 아미노산은 총 16 종
이 검출되었는데, 그 비율과 조성을 측정한 결과는 다음 Table 5 와 같다. 총 유리 아미노산의 함량은 $\mathrm{C}, \mathrm{T} 1, \mathrm{~T} 2$ 및 T3에서 각각 $349.0 \mathrm{mg}, 260.7 \mathrm{mg}, 234.5 \mathrm{mg}$ 및 $217.4 \mathrm{mg} / 100$ $\mathrm{g}$ 로 비살균구에서 가장 높게 측정되었다. 또한, 처리구 중 에서는 $\mathrm{T} 1, \mathrm{~T} 2, \mathrm{~T} 3$ 의 순으로 $\mathrm{F}_{0}$ 값이 증가할수록 총 유리 아미노산의 함량이 감소하는 경향을 나타냈지만 유의적인 차이는 없는 것으로 확인되었다(p>0.05). 식품의 유리 아미 노산 함량은 기호성에 영향을 미칠 뿐만 아니라 풍미를 예측하는 중요한 요소가 될 수 있다. 풍미는 감칠맛 계 (aspartic acid, glutamic acid), 단맛 계(threonine, serine, glutamine, proline, glycine, alanine, lysine), 쓴맛 계(valine, methionine, isoleucine, leucine, phenylalanine, histidine, arginine), 그리고 황화합물과 비슷한 맛(cysteine, methionine) 으로 분류된다(26,27). 본 연구에서는 $\operatorname{Kim}(28)$ 의 분류 방법 에 따라 유리 아미노산을 크게 필수 아미노산, 맛난 맛 성분 의 아미노산, 나머지 모든 아미노산으로 구분하였다. 삼계 탕 가슴살 시료에서의 필수 아미노산의 양은 $\mathrm{C}(122.6$ $\mathrm{mg} / 100 \mathrm{~g}), \mathrm{T} 1(103.2 \mathrm{mg} / 100 \mathrm{~g}), \mathrm{T} 2(87.4 \mathrm{mg} / 100 \mathrm{~g})$ 와

Table 5. Free amino acid compositions of retorted Samgyetang breast meats treated with different $\mathrm{F}_{0}$-values

(unit: $\mathrm{mg} / 100 \mathrm{~g}$ )

\begin{tabular}{|c|c|c|c|c|c|}
\hline \multirow{2}{*}{\multicolumn{2}{|c|}{ Amino acid }} & \multirow{2}{*}{ Control $^{1)}$} & \multicolumn{3}{|c|}{ Treatments ${ }^{2)}$} \\
\hline Amin & & & $\mathrm{T} 1$ & $\mathrm{~T} 2$ & $\mathrm{~T} 3$ \\
\hline \multirow{9}{*}{ Essential amino acid } & Histidine & $8.9 \pm 0.00^{3 / 24)}$ & $6.3 \pm 0.00^{b}$ & $6.0 \pm 0.00^{c}$ & $4.9 \pm 0.01^{\mathrm{d}}$ \\
\hline & Arginine & $18.6 \pm 0.00^{\mathrm{a}}$ & $17.4 \pm 0.01^{\mathrm{b}}$ & $15.2 \pm 0.03^{\mathrm{c}}$ & $15.2 \pm 0.01^{\mathrm{c}}$ \\
\hline & Threonine & $11.5 \pm 0.01^{\mathrm{a}}$ & $8.4 \pm 0.00^{b}$ & $7.2 \pm 0.06^{c}$ & $7.1 \pm 0.01^{\mathrm{d}}$ \\
\hline & Valine & $14.2 \pm 0.01^{\mathrm{a}}$ & $11.6 \pm 0.00^{\mathrm{b}}$ & $9.9 \pm 0.03^{\mathrm{c}}$ & $9.5 \pm 0.01^{\mathrm{d}}$ \\
\hline & Methionine & $9.6 \pm 0.01^{\mathrm{a}}$ & $8.0 \pm 0.00^{b}$ & $6.4 \pm 0.03^{c}$ & $5.5 \pm 0.00^{\mathrm{d}}$ \\
\hline & Lysine & $22.3 \pm 0.03^{\mathrm{a}}$ & $18.2 \pm 0.02^{\mathrm{b}}$ & $14.4 \pm 0.10^{\mathrm{c}}$ & $13.1 \pm 0.02^{\mathrm{d}}$ \\
\hline & Isoleucine & $10.1 \pm 0.01^{\mathrm{a}}$ & $8.2 \pm 0.02^{\mathrm{b}}$ & $7.0 \pm 0.10^{c}$ & $5.8 \pm 0.01^{\mathrm{d}}$ \\
\hline & Leucine & $16.7 \pm 0.01^{\mathrm{a}}$ & $14.6 \pm 0.00^{\mathrm{b}}$ & $11.5 \pm 0.04^{\mathrm{c}}$ & $10.5 \pm 0.02^{\mathrm{d}}$ \\
\hline & Phenylalanine & $10.7 \pm 0.05^{\mathrm{a}}$ & $9.5 \pm 0.00^{b}$ & $7.8 \pm 0.01^{\mathrm{c}}$ & $7.3 \pm 0.01^{\mathrm{d}}$ \\
\hline \multicolumn{2}{|c|}{ Subtotal } & $123.6 \pm 4.48^{\mathrm{a}}$ & $105.2 \pm 4.20^{b}$ & $87.4 \pm 3.35^{\mathrm{bc}}$ & $81.9 \pm 3.45^{\mathrm{c}}$ \\
\hline \multirow{6}{*}{$\begin{array}{l}\text { Flavor enhancing amino } \\
\text { acid }\end{array}$} & Aspartic acid & $20.6 \pm 0.02^{\mathrm{a}}$ & $13.9 \pm 0.00^{\mathrm{b}}$ & $11.6 \pm 0.05^{\mathrm{c}}$ & $10.9 \pm 0.00^{\mathrm{d}}$ \\
\hline & Serine & $15.6 \pm 0.00^{\mathrm{a}}$ & $12.4 \pm 0.00^{\mathrm{b}}$ & $10.0 \pm 0.03^{\mathrm{c}}$ & $9.1 \pm 0.00^{\mathrm{d}}$ \\
\hline & Glutamic acid & $134.7 \pm 0.03^{\mathrm{a}}$ & $84.0 \pm 0.00^{\mathrm{b}}$ & $83.8 \pm 0.02^{\mathrm{c}}$ & $77.0 \pm 0.00^{d}$ \\
\hline & Glycine & $12.9 \pm 0.03^{\mathrm{a}}$ & $11.4 \pm 0.01^{\mathrm{b}}$ & $10.6 \pm 0.06^{\mathrm{c}}$ & $9.8 \pm 0.01^{\mathrm{d}}$ \\
\hline & Alanine & $22.3 \pm 0.01^{\mathrm{a}}$ & $18.3 \pm 0.01^{\mathrm{b}}$ & $16.2 \pm 0.02^{\mathrm{c}}$ & $15.7 \pm 0.00^{\mathrm{d}}$ \\
\hline & Tyrosine & $11.5 \pm 0.01^{\mathrm{a}}$ & $10.6 \pm 0.01^{b}$ & $8.8 \pm 0.04^{\mathrm{c}}$ & $7.1 \pm 0.01^{\mathrm{d}}$ \\
\hline \multicolumn{2}{|c|}{ Subtotal $^{\text {NS5) }}$} & $217.6 \pm 45.47$ & $150.6 \pm 27.22$ & $141.0 \pm 27.85$ & $129.6 \pm 25.64$ \\
\hline Derivative amino acid & Proline & $8.8 \pm 0.03^{\mathrm{a}}$ & $6.9 \pm 0.01^{b}$ & $6.1 \pm 0.04^{c}$ & $5.9 \pm 0.00^{d}$ \\
\hline \multicolumn{2}{|c|}{ Total $^{\text {NS }}$} & $349.0 \pm 29.80$ & $260.7 \pm 17.99$ & $234.5 \pm 18.28$ & $217.4 \pm 16.91$ \\
\hline
\end{tabular}

\footnotetext{
${ }^{1)}$ Control, non-retorted sample.

${ }^{2)} \mathrm{F}_{0}$-value range of treatments: $\mathrm{T} 1,10 \sim 20 ; \mathrm{T} 2,20 \sim 30 ; \mathrm{T} 3,>30$.

${ }^{3)}$ Values are mean $\pm \mathrm{SD}$.

${ }^{4)-d}$-different superscripts in the same row are significantly different $(\mathrm{p}<0.05)$.

${ }^{5} \mathrm{NS}$, Not significant.
} 
$\mathrm{T} 3(81.9 \mathrm{mg} / 100 \mathrm{~g})$ 으로 $\mathrm{F}_{0}$ 값이 증가할수록 유의적으로 낮아 지는 경향을 나타냈다 $(\mathrm{p}<0.05)$.

$\mathrm{F}_{0}$ 값별 가슴살에서 추출한 맛난 맛 아미노산으로서 aspartic acid, serine, glutamic acid, glycine, alanine 및 tyrosine이 검출되었다. 특히 glycine과 alanine은 단맛을 내 는 아미노산인데 정미성분으로 중요하며(29), glutamic acid 는 맛난 맛을 내는 성분으로 고기 맛에 영향을 준다(30). 맛난 맛 아미노산 합계는 $\mathrm{C}(217.6 \mathrm{mg} / 100 \mathrm{~g}), \mathrm{T} 1(150.6$ $\mathrm{mg} / 100 \mathrm{~g}), \mathrm{T} 2(141.0 \mathrm{mg} / 100 \mathrm{~g})$ 와 T3(129.6 mg/100 g)로 $\mathrm{F}_{0}$ 값이 증가할수록 총 유리 아미노산의 함량이 감소하는 경향을 나타냈지만 유의적인 차이는 없는 것으로 확인되었 다( $\mathrm{p}>0.05)$.

\section{경도 및 탄성도}

$\mathrm{F}_{0}$ 값별 레토르트 삼계탕 가슴살과 뼈의 경도 및 탄성도 결과는 Table 6에 나타나 있다. 가열처리되지 않은 가슴살 (C)의 경도는 $19.50 \mathrm{~kg} / \mathrm{m}^{2}$ 이었는데 반하여, 가열처리구인 $\mathrm{T} 1, \mathrm{~T} 2$ 및 T3는 각각 $15.70 \mathrm{~kg} / \mathrm{m}^{2}, 12.80 \mathrm{~kg} / \mathrm{m}^{2}$ 과 $11.20 \mathrm{~kg} / \mathrm{m}^{2}$ 로 $\mathrm{F}_{0}$ 값 수준이 높아질수록 유의적으로 낮아지는 경향을 나타냈다. 살균 처리되지 않은 가슴살 $(\mathrm{C})$ 의 탄성도는 $83.50 \%$ 이었는데 반하여, $\mathrm{T} 1, \mathrm{~T} 2$ 및 $\mathrm{T} 3$ 는 각각 $79.30 \%$, $79.20 \%, 79.10 \%$ 로서 경도와 마찬가지로 $\mathrm{F}_{0}$ 값이 증가할수 록 유의적으로 감소하는 경향을 나타냈다 $(\mathrm{p}<0.05)$.

Malick 등(31)은 $\mathrm{F}_{0}$ 값을 $5,7,9$ 로 각각 처리한 인도 흰 새우 레토르트 파우치 제품의 경도와 탄성도가 $\mathrm{F}_{0}$ 값 수준이 높아질수록 낮게 측정되었다고 보고하였다. 또한 Roldán 등(32)도 양고기 허리살의 경우 높은 온도로 가열된 시료일 수록 제품의 경도와 탄성도가 낮게 측정되었다고 보고하여
상기 결과를 뒷받침하였다. 이와 같은 현상은 콜라겐 단백 질이 젤라틴화되고 육단백질 매트릭스가 파괴되는데 기인 한 것으로 추정되며, 이로 인하여 제품의 저작감이 저하되 어 품질이 열등해지는 결과를 초래한 것으로 판단된다 $(33,34)$.

가열처리되지 않은 삼계탕 시료(C) 중 빼의 경도는 $163.80 \mathrm{~kg} / \mathrm{m}^{2}$ 이었는데 반하여, 가열처리구인 T1, T2 및 T3 는 각각 $126.00 \mathrm{~kg} / \mathrm{m}^{2}, 89.50 \mathrm{~kg} / \mathrm{m}^{2}$ 와 $66.60 \mathrm{~kg} / \mathrm{m}^{2}$ 로서 $\mathrm{F}_{0}$ 값 수준이 높아질수록 낮아지는 경향을 나타내었지만 유의적 인 차이는 아니었다(p>0.05). 가열처리되지 않은 삼계탕 시 료(C) 중 뼈의 탄성도는 $97.67 \%$ 이었는데 반하여, 가열처리 구인 $\mathrm{T} 1, \mathrm{~T} 2$ 및 $\mathrm{T} 3$ 는 각각 $95.52 \%, 95.53 \%$ 와 $95.53 \%$ 로 $\mathrm{F}_{0}$ 값 수준이 높아질수록 유의적으로 낮아지는 경향을 나타 냈다.

$\mathrm{Yoo}$ 등(16)도 $121^{\circ} \mathrm{C}$ 에서 30 분, 50 분, 70 분 및 90 분으로 각각 가열된 레토르트 삼계탕의 뼈 연화 강도를 측정한 결과 본 시험의 결과와 마찬가지로 가열온도가 높고 처리시 간이 길수록 파쇄강도는 약해지는 것으로 나타났으며 뼈 연화 정도에 따른 선호도는 강도가 높을수록 관능검사의 결과도 상대적으로 우수한 것으로 나타나 $\mathrm{F}_{0}$ 값을 최대한 낮게 유지하는 것이 관능학적인 품질향상 차원에서 중요한 요소라고 사료된다.

탁 도

$\mathrm{F}_{0}$ 값별 레토르트 삼계탕의 탁도 측정 결과는 Table 6에 나타나 있다. 가열처리되지 않은 시료(C)의 탁도는 $0.05 \%$ 이었는데 반하여, 가열처리구인 $\mathrm{T} 1, \mathrm{~T} 2$ 및 $\mathrm{T} 3$ 는 각각 $0.07 \%$, $0.08 \%$ 와 $0.08 \%$ 로서 $\mathrm{F}_{0}$ 값 수준이 높아질수록 유의적으로

Table 6. Texture, turbidity, and instrumental color values of retorted Samgyetang broths treated with different $\mathrm{F}_{0}$-values

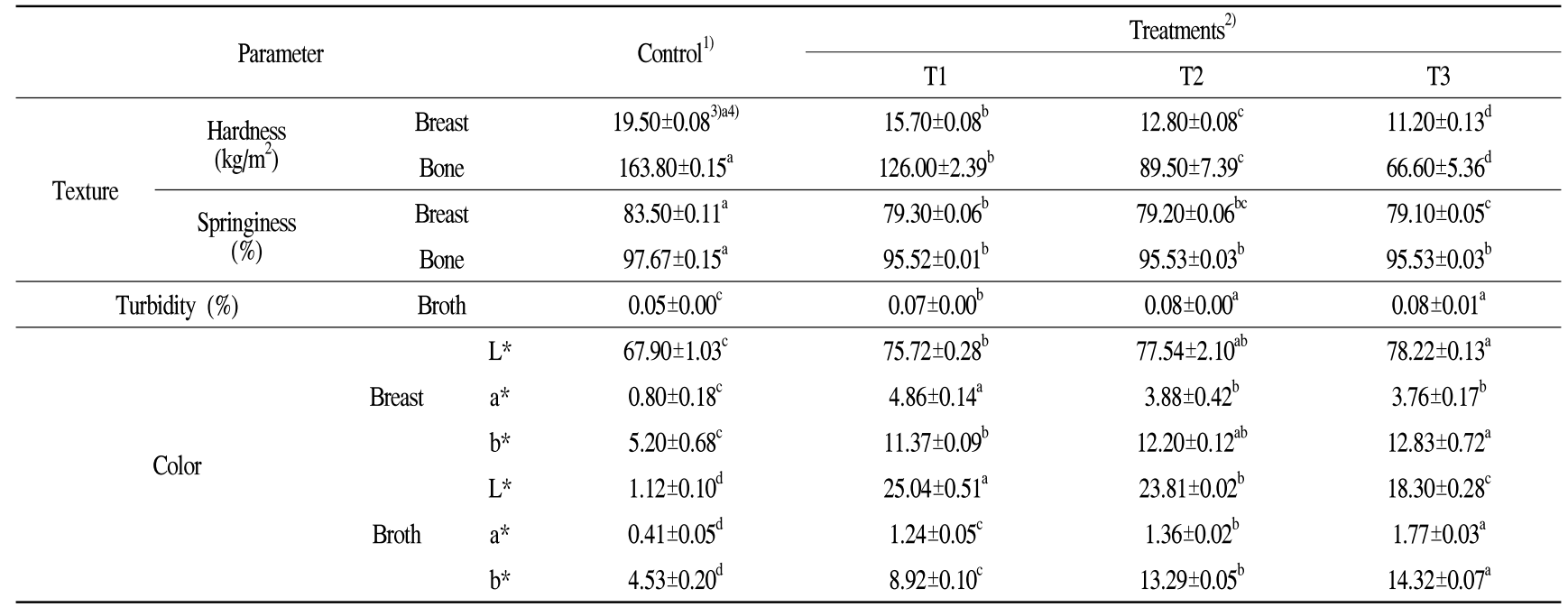

\footnotetext{
${ }^{1)}$ Control, non-retorted sample.

${ }^{2)} \mathrm{F}_{0}$-value range of treatments: $\mathrm{T} 1,10 \sim 20 ; \mathrm{T} 2,20 \sim 30$; $\mathrm{T} 3,>30$.

${ }^{3)}$ Values are mean $\pm S D$.

${ }^{4)-d}$ Different superscripts in the same row are significantly different $(\mathrm{p}<0.05)$
} 
증가하는 경향을 나타내었다(p<0.05). 이는 $\mathrm{Ha}$ 등(35)의 연 구에서 숭늉의 추출온도와 추출시간이 증가할수록 탁도가 증가한다는 결과와 유사하였다. 또한 Foegeding 등(36)은 단백질의 용해성과 혼탁도와는 밀접한 관련성이 있어 가열 에 의해 미오신과 피브리노겐 현탁액의 단백질의 용해성은 감소하는 반면 혼탁도는 증가하였다고 보고하여 본 실험과 유사한 결과를 나타냈다. 이러한 결과들은 레토르트 살균 시 높은 $\mathrm{F}_{0}$ 값에 따른 고온에 의하여 전분 성분들이 변성되 면서 분자 구조가 응집되는 형태로 되거나 소수성기가 분자 표면에 노출됨에 따라 탁도가 증가하는 것으로 판단된다 (37).

\section{색 도}

$\mathrm{F}_{0}$ 값별 레토르트 삼계탕 가슴살과 육수의 색도 측정 결과 는 Table 6에 나타나 있다. 가슴육의 경우 레토르트 살균된 시료의 경우 비살균구에 비해서 $\mathrm{L}^{*}, \mathrm{a}^{*}$ 및 $\mathrm{b}^{*}$ 값이 높아졌다. 그리고 $\mathrm{F}_{0}$ 값 수준이 높아질수록 $\mathrm{L}^{*}$ 값과 $\mathrm{b}^{*}$ 값은 높아지고 $\mathrm{a}^{*}$ 값은 낮아지는 경향을 나타냈다. Kilic 등(38)은 식육이 가열에 의하여 myoglobin이 변성되어 육색이 연하여져 $\mathrm{L}^{*}$ 값이 높아지고 $\mathrm{a}^{*}$ 값은 낮아진다고 보고하여 본 연구의 실험 결과와도 일치하는 경향을 나타냈다.

육수에서도 레토르트 살균처리 된 시료의 경우 비살균구 에 비해서 $\mathrm{L}^{*}, \mathrm{a}^{*}$ 및 $\mathrm{b}^{*}$ 값이 증가하는 경향을 보였지만 $\mathrm{F}_{0}$ 값 수준이 높아질수록 $\mathrm{L}^{*}$ 값은 감소하고 $\mathrm{a}^{*}$ 와 $\mathrm{b}^{*}$ 값은 유의적으 로 증가하였다 $(\mathrm{p}<0.05)$. 이상의 결과로 미루어 $\mathrm{F}_{0}$ 값이 높을 수록 명도가 점점 낮아져 색이 짙어진다고 사료된다. 가열 시간에 따른 beef consomme의 기호도 및 이화학적 특성에 관한 연구(39)에서와 같이 가열시간이 증가할수록 $\mathrm{L}^{\star}$ 값이 낮아지고 $\mathrm{a}^{*}$ 와 $\mathrm{b}^{*}$ 값이 증가하는 현상은 본 연구 결과와 유사 하였다. 이와 같은 현상은 육수의 열처리 가공과정 중 아미 노산과 당의 결합으로 갈변물질이 생성되고 시간이 증가할 수록 갈변 물질의 생성이 증가함과 아울러 가혹한 가열 조건으로 인한 탁도와 고형분의 함량이 증가한 것에 기인한 것으로 추측된다(40-42).

\section{향기 패턴 분석}

전자코는 $\mathrm{GC}$ 및 $\mathrm{GCMM}$ 에 비해 냄새와 향기 패턴을 유용 하게 분석할 수 있는 기술인데, 이를 이용하여 $\mathrm{F}_{0}$ 값별 레토 르트 삼계탕 가슴살의 향기 패턴을 도식화하였다(Fig. 2). 가슴살의 제 1 주성분과 제 2 주성분에 대한 기여도는 각각 $99.578 \%$ 와 $0.2243 \%$ 로서 제 1 주성분 값만을 이용하여 향기 패턴의 변화를 인식할 수 있음을 확인하였다. PCA1에 의해 서 $\mathrm{T} 1\left(\mathrm{~F}_{0}\right.$ 값 10 20)과 $\mathrm{T} 2\left(\mathrm{~F}_{0}\right.$ 값 20 30)는 양의 방향, $\mathrm{T} 3\left(\mathrm{~F}_{0}\right.$ 값 30 40)구는 음의 방향에 멀리 떨어져 위치하여 $\mathrm{T} 1$ 과 $\mathrm{T} 2$ 에 비해 T3구의 향기가 더 약한 것을 알 수 있었다. PCA2에 의해서는 세 시료 모두 다른 방향에 위치하여 향기 패턴이 뚜렷하게 구분되었다. 또한 분별지수(discrimination index)
는 처리구들의 향기패턴 간에 차이를 나타내는 지수로서 그 수치가 음수로 감소할수록 차이가 작아지고, 양수로 증 가할수록 커지는 것을 의미하는데(43), 본 실험 결과에서는 분별지수가 92 로서 모든 처리구들간의 향기패턴이 극명하 게 차이가 났다.

Bejerholm과 Aaslyng(44)는 $65^{\circ} \mathrm{C}, 75^{\circ} \mathrm{C}$ 와 $85^{\circ} \mathrm{C}$ 로 조리 온 도의 변화를 준 돈육의 품질 분석 연구에서 중심온도의 증가는 고기의 육즙뿐만 아니라 냄새에도 영향을 미친다고 하였다. 또한 $\operatorname{Han}$ 등(45)도 방사선 조사 온도에 따른 타락죽 의 이화학적 품질특성 연구에서 감마선 조사에 의한 향기 성분이 조사온도가 높을수록 증가한다고 보고한 바 있다. 따라서 레토르트 제품의 $\mathrm{F}_{0}$ 값 증가는 향기 패턴에 영향을 미치고 이를 통한 관능적 품질 개선이 필요할 것으로 추측 된다.

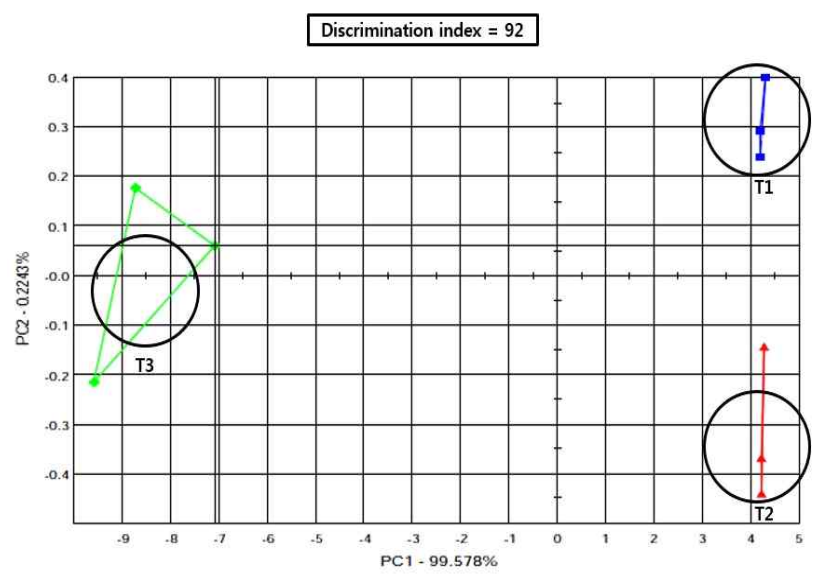

Fig. 2. Discriminant function analysis of the electronic nose data for flavor pattern in retorted Samgyetang breast meats treated with different $\mathrm{F}_{0}$-values.

$\mathrm{F}_{0}$-value range of treatments: $\mathrm{T} 1,10-20 ; \mathrm{T} 2,20-30 ; \mathrm{T} 3,>30$.

관능검사

$\mathrm{F}_{0}$ 값별 레토르트 삼계탕의 색, 조직감, 이취 및 풍미에 대한 관능학적 특성을 비교 조사한 결과는 Table 7에 나타 난 바와 같다. 본 실험에서의 레토르트 삼계탕의 관능검사

Table 7. Sensory scores of retorted Samgyetangs treated with different $\mathrm{F}_{0}$-values

\begin{tabular}{cccc}
\hline \multirow{2}{*}{$\begin{array}{c}\text { Sensory } \\
\text { parameters }\end{array}$} & \multicolumn{3}{c}{ Treatments $^{1)}$} \\
\cline { 2 - 4 } & $\mathrm{T} 1$ & $\mathrm{~T} 2$ & $\mathrm{~T} 3$ \\
\hline Color & $\left.8.4 \pm 0.46^{2 \mathrm{a} 3}\right)$ & $8.0 \pm 0.24^{\mathrm{a}}$ & $7.5 \pm 0.67^{\mathrm{b}}$ \\
Off-odor & $8.4 \pm 0.47^{\mathrm{a}}$ & $8.0 \pm 0.47^{\mathrm{ab}}$ & $7.7 \pm 0.67^{\mathrm{b}}$ \\
Texture & $8.8 \pm 0.26^{\mathrm{a}}$ & $8.2 \pm 0.34^{\mathrm{b}}$ & $7.6 \pm 0.52^{\mathrm{c}}$ \\
Flavor & $8.5 \pm 0.41^{\mathrm{a}}$ & $8.1 \pm 0.39^{\mathrm{b}}$ & $7.8 \pm 0.42^{\mathrm{b}}$ \\
\hline
\end{tabular}

${ }^{1)} \mathrm{F}_{0}$-value range of treatments: $\mathrm{T} 1,10 \sim 20 ; \mathrm{T} 2,20 \sim 30 ; \mathrm{T} 3,>30$.

${ }^{2)}$ Values are mean \pm SD.

3)-CDifferent superscripts in the same row are significantly different $(\mathrm{p}<0.05)$. 
에 대한 결과를 보면 $\mathrm{T} 1, \mathrm{~T} 2$ 와 $\mathrm{T} 3$ 시료에서의 육색이 8.4, 8.0 과 7.5점으로 평가되었는데 이러한 경향은 조직감, 이취 및 풍미 평가 항목에서도 유사하게 나타났다. $\mathrm{F}_{0}$ 값이 증가 함에 따라 모든 관능학적 평가 항목에서 유의적으로 낮은 선호도를 보였다. Lee 등(3)에 따르면 $\mathrm{F}_{0}$ 값 수준이 높을수록 12 개월간 저장 중 제품의 관능학적 품질이 낮게 평가되는 경향을 보였다고 보고하여, 초기 품질 차이가 저장 기간 중에도 확인되는 것으로 추정된다.

\section{요 약}

국내 삼계탕 제조업체에서의 스팀식 레토르트기내 위치 별 $\mathrm{F}_{0}$ 분포를 조사하고 이에 따라 시료를 3 가지 $\mathrm{F}_{0}$ 값(10 20, 20 30, 및 >30) 수준으로 구분하여, 처리구별 품질 차이를 확인하였다. $\mathrm{F}_{0}$ 값의 수준이 높아질수록 삼계탕 가슴부위육 의 육수에서의 무기질 함량, 육의 $\mathrm{L}^{*}$ 과 $\mathrm{b}^{*}$ 값, 죽과 육에서의 소화율 및 육수의 탁도는 증가하는 경향을 보였고, 육에서 의 유리 아미노산 함량과 가슴살과 뼈의 경도는 오히려 유의적으로 낮아지는 경향을 보였다. 전자코로 측정된 육 수와 가슴살의 향기 패턴은 시료에 따라 큰 차이를 나타냈 다. 관능학적 평가 결과 높은 $\mathrm{F}_{0}$ 값으로 처리할수록 색, 이취, 조직감 및 향미 등 모든 지표 값이 낮아지는 경향이 확인되 었는데, 특히 $\mathrm{T} 3$ 시료의 색과 조직감은 $\mathrm{T} 1$ 과 $\mathrm{T} 2$ 시료에서보 다 확실히 열등하게 평가되었다. 따라서 삼계탕의 품질 열 화를 줄이기 위해서는 가능한 한 최소한의 $\mathrm{F}_{0}$ 값 처리가 요구되며, 이를 위해서는 레토르트기의 우수한 성능과 효 율성이 보장되고 이와 관련한 각 공장에 적합한 살균기술의 표준화가 필요할 것으로 사료된다.

\section{감사의 글}

본 논문은 농림수산식품부 농림기술개발사업의 지원으 로 이루어진 연구결과로 연구비지원에 감사드립니다.

\section{References}

1. Park YH (2004) The effects of serum lipids and blood glucose on retort Samgyetang intake in rats. J Korean Home Economics Association, 42, 143-152

2. Oh SY (2001) A study on the developing direction of new Samgyetang products. Korean J Food Sci Ani Resour, 21, 103-109

3. Lee JH, Lee JH, Lee KT (2014) Physicochemical and sensory characteristics of Samgyetang retorted at different
$\mathrm{F}_{0}$ values during storage at room temperature. Korean Soc Food Preserv, 21, 491-499

4. Lee, JH, Lee KT (2009) Studies on the improvement of packaging retorted Samgyetang. Korean J Packaging Sci Technol, 15, 49-54

5. Kang JY, Yun JU, Hwang SM, Kang JG, Kim NW, Oh KS (2010) Effects of retort sterilization on quality characteristics of the imitation crab leg. J Agri Life Sci, 44, $147-157$

6. Plug IJ, Borrero C (1967) Heating media for processing food in flexible packages. Phase II Tech Rep 67-47-GP, US Army Natick Laboratories, MA, USA

7. Berry R Jr (1979) The sterilization of food in pouches-critical parameters for still processing. Using retort pouches worldwide-focus on the present with a look to the future. Indianapolis, USA, p 14-15

8. Ohlsson T (1980) Optimal sterilization temperature for flat containers. J Food Sci, 45, 848-852

9. Casales MR, Del Valle CE, Soule CL (1988) Heat penetration in canned mussels during agitated retorting. J Food Sci, 53, 4-5

10. Kimbell RN, Heyliger TL (1990) Verifying the operation of steam retorts. Food Technol, 12, 100-103

11. Chung MS, Ahn TH, Lee YG, Yoo MY (1995) Temperature distribution in water cascading horizontal retort. Korean J Food Sci Technol, 27, 827-833

12. Smout C, Avila I, Van Loey AML, Hendrickx MEG, Silva C (2000) Influence of rotational speed on the statistical variability of heat penetration parameters and on the non-uniformity of lethality in retort processing. J Food Eng, 45, 93-102

13. Chen CR, Ramaswamy HS (2002) Modeling and optimization of variable retort temperature thermal processing using coupled neural networks and genetic algorithms. J Food Eng, 53, 209-220

14. Park SW, Kim ST, Yoo YG (1993) Mineral content in Samgyetang broth according to cooker and boiling time. Korean J Soc Food Sci, 9, 52-56

15. Seo SH, Kim EM, Kim YB, Cho EK, Woo HJ (2014) A study on development of Samgyetang using superheated steam and high hydrostatic pressure. Korean J Food Cook Sci, 30, 183-192

16. Yoo IJ, Jeon KH, Park WM, Choi SY (1999) Effect of heating conditions and additives on bone crumble and shelf-life of retorted Samgyetang. Korean J Food Sci Ani Resour, 19, 19-26

17. Lowry OH, Rosebrough NJ, Farr AL, Randall RJ (1951) 
Protein measurement with the Folin phenol reagent. J Biol Chem, 193, 265-275

18. Yamashita M, Arai S, Kokubo S, Aso K, Fujimaki M (1975) Synthesis and characterization of a glutamic acid enriched plastein with greater solubility. J Agric Food Chem, 23, 27-30

19. Smyth AB, O'Neill E (1997) Heat-induced gelation properties of Surimi from mechanically separated chicken. J Food Sci, 62, 326-330

20. Wattanachant S, Benjakul S, Ledward DA (2005) Effect of heat treatment on changes in texture, structure and properties of Thai indigenous chicken muscle. Food Chem, 93, 337-348

21. Cho KH (1994) Effect of microwave cooking on roasts heated to three different internal temperatures with three different microwave power levels. Korean J Food Cook Sci, 10, 394-404

22. Son DY, Lee BR, Shon DW, Lee KS, Ahn KM, Nam SY, Lee SI (2000) Allergenicity change of soybean proteins by thermal treatment. Korean J Food Sci Technol, 32, 959-963

23. Hoppe A, Jung S, Patnaik A, Zeece MG (2013) Effect of high pressure treatment on egg white protein digestibility and peptide products. Innov Food Sci Emerging Technol, 17, 54-62

24. Sun M, Mu T, Zhang M, Arogundade LA (2012) Nutritional assessment and effects of heat processing on digestibility of Chinese sweet potato protein. J Food Composition Anal, 26, 104-110

25. Promeyrat A, Gatellier P, Lebret B, Kajak-Siemaszko M, Aubry L, Sante-Lhoutellier V (2010) Evaluation of protein aggregation in cooked meat. Food Chem, 121, 412-417

26. Watanabe K, Sato Y (1974) Meat flavor. Japan J Zootec Sci, 45, 113-128

27. Rikimura K, Takahashi H (2010) Evaluation of the meat from Honey-Dijon chicken and broilers: Analysis of general biochemical components, free amino acids, inosine-5'-monophosphate, and fatty acids. J Poult Res, $19,327-333$

28. Kim HD (2004) The mineral contents, viscosity and sensory characteristics of demi-glace sauce according to the varying quantity of Omija added. Korean J Food Culture, 19, 667-677

29. Park HO, Lee HJ (1995) A study on the free amino acid minerals of chicken bone extracts by boiling time. Korean J Soc Food Sci, 11, 244-248
30. Lee JM, Kim KO, Choi SE (2000) Effect of soaking and blanching chicken-head in the preparation of chicken head broth. Korean J Food Sci Technol, 32, 674-680

31. Mallick AK, Gopal TK, Ravishankar CN, Vijayan PK, Geethalakshmi V (2010) Changes in instrumental and sensory properties of indian white shrimp in curry medium during retort pouch retort pouch processing at different $\mathrm{F}_{0}$ values. J Texture Studies, 41, 611-632

32. Roldan M, Antequera T, Martin A, Mayoral AI, Ruiz J (2013) Effect of differen temperature-time combinations on physicochemical, microbiological, textural and structural features of sous-vide cooked lamb loins. Meat Sci, 93, 572-578

33. Dierick A, Vandekerckhove P, Demeyer D (1974) Changes in nonprotein nitrogen compounds during dry sausages ripening. J Food Sci, 39, 301-306

34. Kim IS, Lee SO, Byun JS, Kang JN, Min JS, Lee M (2000) Physicochemical, microbiological and sensory characteristics of frozen loins of Han-woo and imported beef in Korean market. J Anim Sci Technol, 42, 117-124

35. Ha TY, Chun HS, Lee C, Kim YH, Han O (1999) Changes in physicochemical properties of steamed rice for Soong-Neung during roasting. Korean J Food Sci Technol, 31, 171-175

36. Foegeding EA, Allen CE, Dayton WR (1986) Effect of heating rate on thermally formed myosin, fibrinogen and albumin gels. J Food Sci, 51, 104-108

37. Cha BS (1999) Studies on processing conditions for Nooroong-gi powder by liquefaction and gelatinization of rice powder. Korean J Soc Food Sci, 15, 469-474

38. Kilic B, Simsek A, Claus JR, Atilgan EA (2014) Encapsulated phosphates reduce lipid oxidation in both ground chicken and ground beef during raw and cooked meat storage with some influence on color, $\mathrm{pH}$, and cooking loss. Meat Sci, 97, 93-103

39. Kim YS, Jang MS (2003) The study of acceptance and physicochemical characteristics of beef consomme by boiling time. Korean J Soc Food Cookery Sci, 19, 271-279

40. Lee SH, Lee YR, Hwang IG, Woo KS, Kim KH, Kim $\mathrm{KJ}$, Jeong HS (2009) Antioxidant activities and quality characteristics of germinated rough rice tea according to roasting temperature, time and leaching condition. Korean J Food Sci Technol, 41, 386-391

41. Kim MJ, Kim MH, Kim SD (2003) Effect of water extracts of shellfish shell on fermentation and calcium content of Kimchi. J Korea Soc Food Sci Nutr, 32, 
161-166

42. Kim JH, Lee HG, Park JH, Ryu JD (2004) Effect of dill and stevia hot-water extracts on quality and sensory characteristics of Kimchi. Korean J Food Nutr, 17, 25-31

43. Cho WH (2010) Studies on the utilization of raw chickens and the development of different seasoning recipe of Chuncheon Dakgalbi. MS Thesis, Kangwon University, Korea
44. Bejerholm C, Aaslyng MD (2004) The influence of cooking technique and core temperature on results of a sensory analysis of pork-depending on the raw meat quality. Food Quality and Preference, 15, 19-30

45. Han IJ, Song BS, Lee JW, Kim JH, Choi KS, Park JR, Chun SS (2011) Effect of irradiation temperature on physicochemical and sensory properties of Tarakjuk (milk porridge). J Korean Soc Food Sci Nutr, 40, 1307-1313 